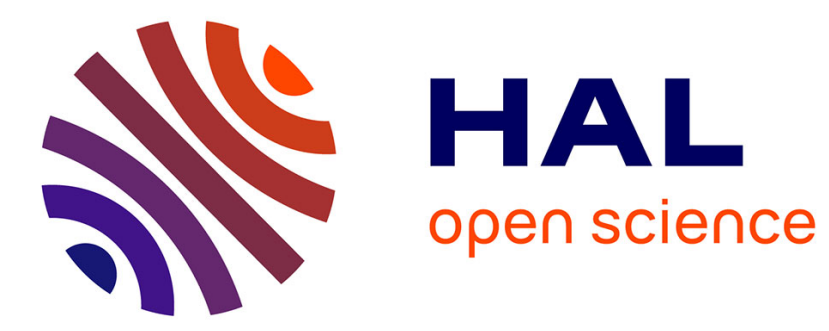

\title{
Grouping patterns, reproduction and dispersal in a population of sitatungas (Tragelaphus spekei gratus)
}

Florence Magliocca, Sophie Quérouil, Annie Gautier-Hion

\section{To cite this version:}

Florence Magliocca, Sophie Quérouil, Annie Gautier-Hion. Grouping patterns, reproduction and dispersal in a population of sitatungas (Tragelaphus spekei gratus). Canadian Journal of Zoology, 2002, 80, pp.245-250. 10.1139/Z01-2 . hal-00138093

\section{HAL Id: hal-00138093 https://hal.science/hal-00138093}

Submitted on 23 Mar 2007

HAL is a multi-disciplinary open access archive for the deposit and dissemination of scientific research documents, whether they are published or not. The documents may come from teaching and research institutions in France or abroad, or from public or private research centers.
L'archive ouverte pluridisciplinaire HAL, est destinée au dépôt et à la diffusion de documents scientifiques de niveau recherche, publiés ou non, émanant des établissements d'enseignement et de recherche français ou étrangers, des laboratoires publics ou privés. 


\title{
Grouping patterns, reproduction, and dispersal in a population of sitatungas (Tragelaphus spekei gratus)
}

\author{
Florence Magliocca, Sophie Quérouil, and Annie Gautier-Hion
}

\begin{abstract}
A population of sitatungas (Tragelaphus spekei gratus) living in a forest swamp clearing, Maya Nord, in the Republic of Congo was studied over $3 \frac{1}{2}$ years and its grouping patterns and population dynamics were analysed. The sitatungas in this clearing formed a stable group, which remained in residence. The group (16-36 individuals) functioned like a harem. As a result of intrasexual competition, all the males and some of the females born at Maya left the group before reaching sexual maturity. We hypothesize that this large grouping resulted from the development of a tendency for females to be gregarious for reasons related to food availability. This tendency, combined with an aseasonal pattern of reproduction, favours direct monopolization of females by one male. Social and mating strategies observed at Maya fit the model of "female-defence polygyny" (Emlen and Oring). Our results provide an argument in favour of relating food availability and grouping patterns, and underline the plasticity of social organization and mating strategies in sitatungas.
\end{abstract}

Résumé : Une population de sitatungas (Tragelaphus spekei gratus) vivant sur une clairière forestière marécageuse, Maya Nord, en République du Congo, a été suivie pendant 31/2 ans; la dynamique de la population et les modalités des regroupements ont été analysées. Les sitatungas de la clairière Maya (16-36 individus) formaient un groupe stable et résidaient toute la journée sur la clairière. Ce groupe fonctionnait comme un harem. En raison de la compétition intrasexuelle, tous les mâles et une partie des femelles nés sur la clairière ont quitté le groupe avant leur maturité sexuelle. Ces modalités de groupement semblent résulter des tendances grégaires des femelles induites par les disponibilités alimentaires. Ces tendances, combinées aux patterns de reproduction non saisonniers, favorisent la monopolisation des femelles par un mâle. Les stratégies sociales et reproductives observées concordent avec le modèle de polygynie avec défense des femelles (female-defence polygyny d'Emlen and Oring). Nos résultats fournissent des arguments pour faire le lien entre les disponibilités en nourriture et les modalités de groupement et soulignent la plasticité de l'organisation sociale et des systèmes de reproduction des sitatungas.

\section{Introduction}

Sitatungas (Tragelaphus spekei) are ruminants belonging to the Bovidae (subfamily Tragelaphinae). Three subspecies are recognised: T. s. spekei (Lake Victoria basin); T. s. selousi (Zambesi and Okavango basin); and T. s. gratus (Congo basin; Kingdon 1982). Adult sexual dimorphism includes body size (adult males weigh 75-90 kg and adult females weigh 30-40 kg; Malbrant and MacLatchy 1949), appearance (adult males are uniformly brown and adult females have white stripes), and weaponry (only adult males have horns). The vegetarian diet of these large ungulates implies long rumination periods and a nycthemeral activity rhythm (Owen 1970; Gautier-Hion et al. 1980).

Sitatungas inhabit hydromorphic forests, swamps, and marshes; they enter forest clearings, gallery forests, and for-

Received 20 June 2001. Accepted 19 November 2001.

Published on the NRC Research Press Web site at http://cjz.nrc.ca on 27 February 2002.

F. Magliocca, S. Quérouil, and A. Gautier-Hion. ${ }^{1}$ Station Biologique, Université Rennes 1, Unité Mixte de Recherche $\mathrm{n}^{\mathrm{o}}$ 6552, Centre National de la Recherche Scientifique, 35380 Paimpont, France.

${ }^{1}$ Corresponding author (e-mail: annie.gautier@univ-rennes1.fr). est islands in savannahs when permanent pools are present (e.g., Malbrant and MacLatchy 1949; Owen 1970; Manning 1983; Starin 2000). Although herds of up to 10-15 animals have been observed, sitatungas are described as living either solitarily, especially adult males, in pairs, or in small groups comprising 2 or 3 adults and their offspring (Malbrant and MacLatchy 1949; Kingdon 1982). In Kenya, $46 \%$ of sightings were of solitary animals, $35 \%$ were of pairs, and less than $4 \%$ included five to nine individuals (Owen 1970). Similar results were recorded in Zambia (Manning 1983). Life expectancy in the wild would be around 11-12 years. Captive animals of both sexes reach sexual maturity between 18 and 24 months of age (Manning 1983). Females give birth to one young and mating is not seasonal (Owen 1970).

In the tropical forests of the Republic of Congo, sitatungas regularly visit forest clearings (Vanleeuwe et al. 1998). We took this opportunity to study the structure and dynamics of a population visiting one clearing and test whether ecological factors prevailing at clearings influenced its grouping patterns and mating strategies.

\section{Material and methods}

Study site

The Parc National d'Odzala $\left(2840 \mathrm{~km}^{2}\right)$ is located northwest 
Table 1. Demography of the sitatunga (Tragelaphus spekei gratus) group at the Maya clearing from 1996 to 2000.

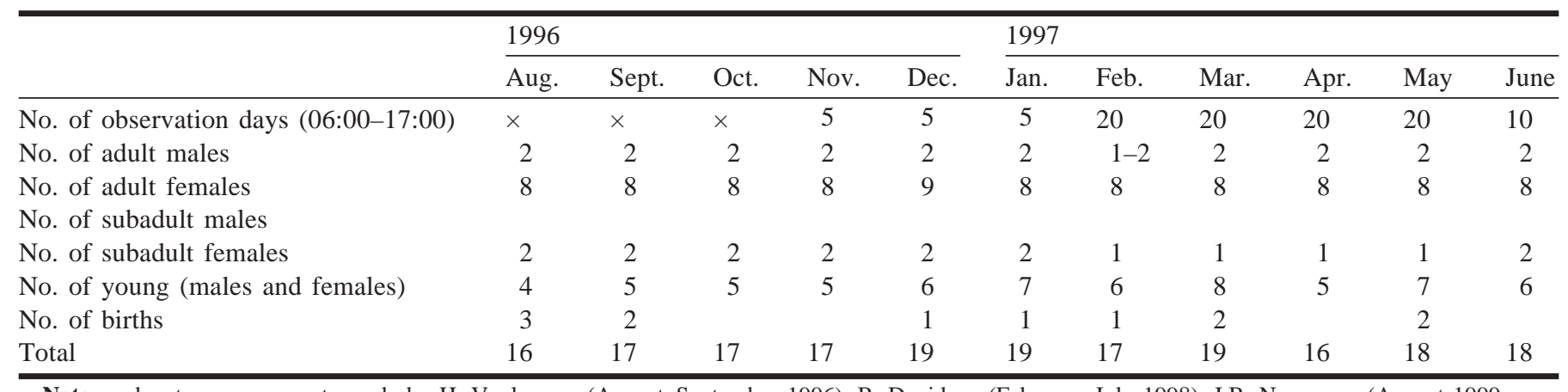

Note: $\times$ denotes group counts made by H. Vanleeuwe (August-September 1996), B. Davidson (February-July 1998), J.B. Nganongo (August 1999 -

*Minimal number of births that occurred during periods when the observers were absent (July 1997 - July 1998 and November 1998 - January 2000$)$.

of the Republic of Congo $\left(00^{\circ} 23^{\prime}-01^{\circ} 10^{\prime} \mathrm{N}, 14^{\circ} 39^{\prime}-15^{\circ} 14^{\prime} \mathrm{E}\right.$; Hecketsweiler et al. 1991). Its northern part is covered with tropical rain forests that include dense forests with a closed canopy and open understorey, huge areas of Marantaceae forests with an open canopy and closed understorey, and periodically flooded forests. About 100 clearings are scattered throughout the forest. Our study was conducted at the Maya Nord (hereinafter Maya) clearing (area $0.2 \mathrm{~km}^{2} ; 01^{\circ} 08^{\prime} \mathrm{N}$, $15^{\circ} 00^{\prime} \mathrm{E}$ ), which was found to be the most visited by large mammals, including sitatungas (T. s. gratus, Sclater, 1864; Vanleeuwe et al. 1998). The Maya clearing is surrounded by a stretch of primary forest a few kilometres wide and then by Marantaceae forests. It is covered by herbaceous vegetation (45 species), mainly Cyperaceae (12 species), Gramineae (5 species), Asteraceae (4 species), and Scrophulariaceae (4 species), and is crossed by several streams. It is periodically flooded during the wet seasons (March-May and SeptemberNovember). As the soil remains wet year-round, the herbaceous vegetation does not dry up and remains permanently available (Magliocca 2000).

\section{Study subjects, study periods, and methods}

Sitatungas have reddish brown flanks with scattered white dots and strips that form a pattern which is unique to each individual. In females these white marks slowly wear away with age. Males' fur gradually turns brownish after they reach 1 year of age. An identification card with a drawing of each individual was prepared, and all group members could be recognised individually. We identified the sex of all adults and subadults because only males possess horns. Because the horns do not grow before males are 6 months old, only $70 \%$ of the young below this age were sexed. Three age classes are described: adults ( $>2-2 \frac{1}{2}$ years), subadults ( 10 months to $2-2 \frac{1}{2}$ years), and young (<10 months) (Manning 1983; Magliocca 2000).

Data were obtained during three observation periods from August 1996 to February 2000 (a total of 137 full days and 1490 observation hours; Table 1). Sitatungas were observed from a $4 \mathrm{~m}$ high platform. The group spread was recorded every $15 \mathrm{~min}$ and plotted on a vegetation map of the clearing. Social interactions, including mutual licking, play, sexual, agonistic, and mother-offspring interactions, were recorded every 15 min. Events such as arrivals or departures, mating, fights, etc. were noted ad libitum. The composition of nocturnal groups observed at sunrise was described.

\section{Results}

\section{Grouping patterns and dynamics}

A number of identified sitatungas were present all day every day at the clearing. They were distributed over less than $13 \%$ of the surface area of the clearing, on average, and maintained inter-individual spacing of as little as $1 \mathrm{~m}$ when feeding or resting. When the Maya clearing was flooded, they stayed at the edges of the clearing. Most sitatungas spent the night at the clearing and were still lying down at sunrise, forming several subgroups scattered in the driest areas. However, on average, $6.5 \%$ of individuals (34\% of these were adult males, $n=114$ ) were observed entering the clearing after sunrise, which suggests that they spent part of the night in the forest. On the basis of inter-individual spacing and site affiliation, and the fact that the same individuals were regularly identified in the population ( 8 of 11 adults identified in 1996 were still present in 2000), we use the term group to describe this population.

Group size varied from 16 to 36 individuals (Table 1). The overall increase in the number of group members was due to a balance between births $(\geq 28)$, immigrations $(\geq 3)$, and emigrations or deaths $(\geq 17)$. The group included two adult males from August 1996 to at least June 1997. From May 1998, only one male was still present. The three age classes (adults, subadults, juveniles) accounted, on average, for $43.5,14$, and $34 \%$ of the group members, respectively. There was an imbalance in favour of females, which increased with age (Table 2).

\section{Sexual cycles, mating patterns, and reproduction}

Table 3 summarizes the main characteristics of the life history of Maya sitatungas. Mating was not seasonal. Female receptivity lasted 2 days, during which time adult and subadult males followed the female continuously, their horns flat on their necks, sniffing her genital area. Mating sequences occurred several times a day; all were performed by the same adult male, which was the most corpulent one. Its tenure lasted at least 44 months. The interval between two oestrous periods was about 20 days and the gestation period was $5 \frac{1}{2}$ months. The age at first mating for females was 2 $2 \frac{1}{2}$ years. Full sexual development of males could be attained by the age of $2^{1 / 2}-3$ years, but because males migrated early, no precise data were obtained. Courtship was first observed in 8-month-old males but no mating occurred.

The 28 births recorded occurred year-round (Table 1). 


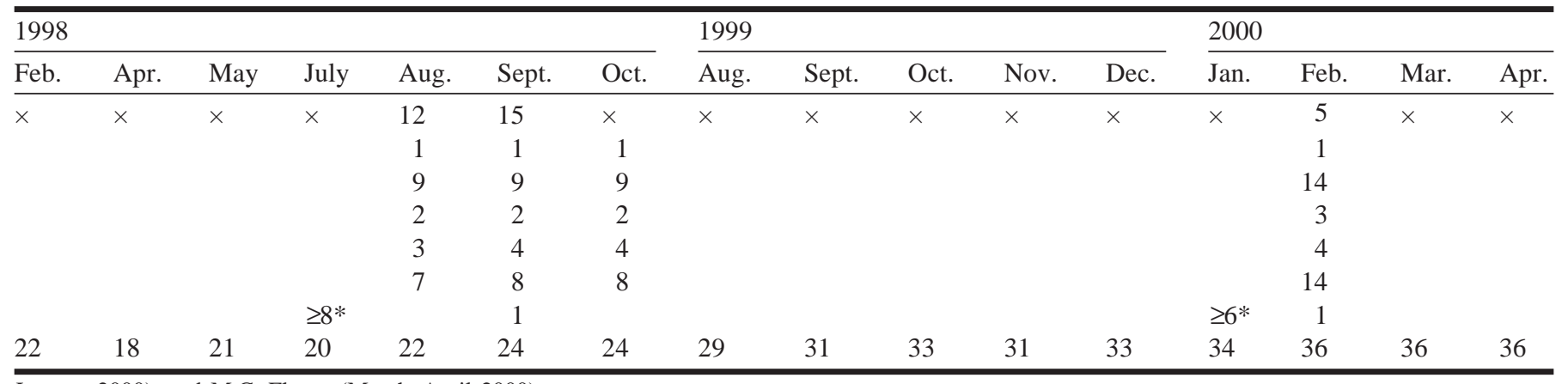

January 2000), and M.C. Fleury (March-April 2000).

One birth was observed during the day (R. Dejace, personal communication). Another time, a female left the clearing during the day to give birth in the forest. Calves remained hidden for at least 2 weeks and suckled until they were 4 months old. The gestation period was $5 \frac{1}{2}$ months and birth intervals ranged from $5 \frac{1}{2}$ to 9 months (Table 3 ). This suggests that postpartum ovulation can occur. From August 1996 to July 1997, 100\% of females reproduced (four of them twice a year, five once). The survival rate for young under 5 months of age was $80 \%$. In 1998 , we estimated that at least $78 \%$ of the adult females had bred.

\section{Dispersal patterns}

The analysis of migrations concerned the period between October 1996 and October 1998. The three immigrations recorded concerned females: the adult female was in oestrous when she arrived (December 1996). In April 2000 she had reproduced at least 3 times. The younger immature female stayed in the group for 4 months, while the older one (which immigrated in August 1998) was still in the group in April 2000 and had reproduced at least once.

Eleven suspected emigrations were recorded. In fact, when a sitatunga disappeared, it was not possible to eliminate predation as the cause. No predation events were recorded during our observations despite visits by hyenas and the presence of crocodiles, pythons, and, once, a leopard. However, predation may have occurred at night. Emigrations concerned three adults (one male and two females) and eight immature individuals (three males, four females, and one animal of unknown sex; $73 \%$ of immigrants). At least one male and one female (5 and $71 / 2$ months old, respectively) left the group when their mother gave birth to a sibling. Two females emigrated after being chased by older females other than their mother. Among the 14 young born during the three study periods, 10 (4 males, 2 females, and 4 animals of unknown sex) emigrated before reaching sexual maturity, while 4 females became reproductive members of the group.

\section{Social behaviour}

The time in the day devoted to social behaviour was low ( $0.6 \%, n=180$ of 32215 scan records), but was probably underestimated by the scan-sampling method. It included play $(0.2 \%)$, mutual licking $(0.1 \%)$, and sexual $(0.1 \%)$, agonistic $(0.1 \%)$, and mother-offspring interactions $(0.1 \%)$. Interactions between adults were limited to sexual and agonistic behaviour. Agonistic interactions involved either
Table 2. Composition and sex ratios of the sitatunga population.

\begin{tabular}{lcccc}
\hline Age/sex class & $\begin{array}{l}\text { Number } \\
(\text { mean } \pm \text { SD) }\end{array}$ & Range & $\begin{array}{l}\text { Percentage } \\
(\text { mean } \pm \text { SD })\end{array}$ & $\begin{array}{l}\text { Sex } \\
\text { ratio }\end{array}$ \\
\hline $\begin{array}{l}\text { Adults } \\
\quad \text { Males }\end{array}$ & $1.7 \pm 0.1$ & $1-2$ & $8.7 \pm 0.9$ & $1: 5$ \\
$\quad \begin{array}{l}\text { Females } \\
\text { Subadults }\end{array}$ & $8.7 \pm 0.4$ & $8-14$ & $43.5 \pm 1.1$ & \\
$\quad$ Males & & & & $1: 3.7$ \\
$\quad$ Females & $0.6 \pm 0.3$ & $0-2$ & $3.0 \pm 1.0$ & \\
$\quad$ Young & $2.2 \pm 0.3$ & $1-8$ & $11.0 \pm 0.9$ & \\
Total in the group & $19.9 \pm 1.2$ & $16-36$ & 100 & $1: 1.5$ \\
\hline
\end{tabular}

males $(n=81)$ or females $(n=54)$. Adult and subadult males confronted each other in fights lasting 1-2 min when they tried to push their rival away with their horns, sometimes rushing forward and hitting heads. These interactions were more frequent (up to 10 fights per day) during a female's period of sexual receptivity. All were initiated by a subadult or by the less corpulent adult male. All chases were won by the stout adult male. Agonistic pursuits involving females lasted about $1 \mathrm{~min}$ and did not include any contact. They were initiated by the older female, which barked. The two oldest adult females in the group were the most aggressive (performing $44.5 \%$ of chases). Immature females were more aggressed than adult females (51 pursuits; $\chi_{[3]}^{2}=27.7$, $p<0.001)$ and immigrant females more than resident females $\left(17\right.$ pursuits; $\left.\chi_{[1]}^{2}=20.7, p<0.001\right)$.

\section{Nocturnal subgroups}

The mean size of nocturnal subgroups was 2.5 individuals (Table 4). A mean of $82 \%$ were female subgroups comprising either subadult and adult females or mothers and offspring, $14 \%$ were mixed-sex subgroups with receptive females, and $4 \%$ were male subgroups. The mother-offspring subgroups were the most stable. However, 5\% of female subgroups included the same members observed at least 10 times, indicating the existence of preferential social affinities. The same preferential subgroups were observed during the daytime resting periods.

\section{Discussion}

During the study period, the sitatunga group in the Maya clearing was sedentary by day. During the night a few individuals, mainly adult males, entered the forest. The group 
Table 3. Main characteristics of the life history of Maya sitatungas.

\begin{tabular}{|c|c|c|}
\hline & & $n$ \\
\hline \multicolumn{3}{|l|}{ Age at first mating } \\
\hline Females & $2-2.5$ years & 3 \\
\hline Males & $>2.5$ years? & \\
\hline Duration of oestrous period & 2 days & 13 \\
\hline $\begin{array}{l}\text { No. of matings per day during } \\
\text { oestrous period }\end{array}$ & $7-12$ & \\
\hline $\begin{array}{l}\text { Interval between two oestrous } \\
\text { periods }\end{array}$ & 19-21 days & 2 \\
\hline Mating period? & No & 13 \\
\hline Birth period? & No & 28 \\
\hline Gestation period & $51 / 2$ months & 1 \\
\hline Interval between two births & 5-9 months & 6 \\
\hline \multicolumn{3}{|l|}{$\begin{array}{l}\text { Reproduction rate for adult } \\
\text { females }(\%)\end{array}$} \\
\hline $1996-1997$ & 100 & 9 \\
\hline 1998 & 78 & 9 \\
\hline Young survival at 5 months & $80 \%(1996-1997)$ & 10 \\
\hline \multicolumn{3}{|l|}{ Age at emigration } \\
\hline Females & 5 months to $>3.5$ years & 9 \\
\hline Males & 7.5 months to $>3.5$ years & 4 \\
\hline Age at immigration (females) & 6 months to $>3$ years & 3 \\
\hline
\end{tabular}

increased regularly in size and its composition varied as a result of births, offspring maturation, and migration. However, the main nucleus of adult females present at the beginning of the study was still present $3 \frac{1}{2} 2$ years later, and the tenure of the dominant adult male which completed all matings was maintained over this period. The subordinate male, which was the loser in all agonistic interactions with the other adult male, was never seen to complete a mating. All identified young males born at the clearing emigrated before becoming sexually mature, most often after fights with the dominant adult male. Thus, the group functions like a harem as a result of intrasexual competition, which induces the dispersal of subadult males and establishes a hierarchy that limits access to reproduction to one male. No adult male intruder was seen entering the Maya clearing, suggesting that the clearing was viewed as a territory. However, conflicts may have occurred by night.

Four females born at Maya became reproductive members of the group, while two other females and four individuals of unknown sex left the clearing before reaching sexual maturity, either after being chased by adult females or after the birth of a sibling. Since adult females chase young females, they could control access to the reproductive adult male (Rubenstein 1986). Meanwhile, the existence of a dominance hierarchy based on age among adult females could induce inter-individual variation in their reproductive success. Such despotic tendencies frequently characterize social organization in mammals, especially ruminants and primates (e.g., Verhencamp 1983; Cheney et al. 1988; Sterck et al. 1997).

The "female-defence polygyny" model developed by Emlen and Oring (1977) is hypothesized to evolve when females tend to develop a tendency to be gregarious for reasons related to reproduction or food acquisition; this tendency favours direct monopolization by male(s), which aggressively
Table 4. Composition of nocturnal sitatunga subgroups.

\begin{tabular}{lcll}
\hline Subgroup & Percentage & $\begin{array}{l}\text { Mean } \\
\text { size }\end{array}$ & $\begin{array}{l}\text { No. of } \\
\text { individuals }\end{array}$ \\
\hline $\begin{array}{l}\text { Mother-offspring } \\
\text { Adult and subadult females }\end{array}$ & 34.3 & 2.0 & 268 \\
$\quad$ with or without young & 47.4 & 2.7 & 489 \\
$\begin{array}{l}\text { Subadult and (or) adult males + } \\
\quad \text { females with and without young }\end{array}$ & 14.3 & 3.2 & 175 \\
$\quad \begin{array}{llc}\text { Subadult or adult males } \\
\quad \text { Total }\end{array}$ & 4 & 2.1 & 31 \\
& 384 & 2.5 & 963 \\
\hline
\end{tabular}

exclude other males from the area. The potential for males to monopolize females increases when there is asynchrony in female sexual receptivity and (or) females do not forage over large areas (Gosling 1986). Such dominance-determined access to receptive females is more frequent when sexual dimorphism is important (Jarman 1974). Finally, this system frequently occurs in conjunction with male-resource defence by females.

The mating strategies observed at the Maya clearing fit this model. There was no breeding synchrony; one highly dimorphic male monopolized females that participated in the maintenance of the harem structure by trying to exclude immigrating females and young females born at the clearing. The tendency of females to form a group affiliated with a stable home range may result from the availability of an exceptional foraging site with predictable and diversified herbaceous plants, available year-round and rich in mineral salts (Na, Ca; Magliocca and Gautier-Hion 2002), and with seeds deposited in elephant dung, which occupy $20-50 \%$ of the feeding time of sitatungas (Magliocca 2000). Thus, the Maya clearing allows females to gather and remain sedentary in a small area, giving a male the opportunity to monopolize them.

The size and the stability of the Maya sitatunga group differ from previous descriptions of smaller, occasional, and unstable groups in this species (Malbrant and MacLatchy 1949; Owen 1970; Kingdon 1982; Manning 1983; Starin 2000) and a related forest species (Tragelaphus eurycerus) visiting clearings in the Central Africa Republic, whose groupings were not fixed units and varied over short periods (Klaus-Hügi 1998). On the other hand, based on the composition of nocturnal subgroups, our results confirm that interindividual affinities are more developed within than between the sexes (J. May and R. Lindholm, personal communication).

Among the proximate factors that may influence grouping patterns, many authors have stressed the role of openness of the habitat, predation risk, temporal and spatial distribution of food, and modes of exploiting food (e.g., Crook 1970; Estes 1971; Jarman 1974; Rubenstein 1986). Among these factors, Jarman (1974) pointed out the principal influence of food resources. According to his classification, sitatungas fall within the antelopes, which are selective grazers and browsers and live in small groups (two to four individuals) on a stable home range generally defended by a single male. The Maya sitatungas ate many plants but selected plant parts, mostly taking the tips of grass leaves or young leaves and stems of browse, and foraged selectively on seeds of two plant species they find in elephant dung (Magliocca 
2000). They were sedentary and occupied a small exclusive home range, at least during the day. However, they differed from Jarman's model by the large size of their group, which could provide better protection against predators.

The absence of a mating season, the high reproduction rate (with the possibility of two calves per year per female), and the high survival rate of young underline the favourable conditions encountered at the Maya clearing. Indeed, in bovine species subjected to seasonal food shortage, mating is seasonal and reproduction rates are lower than those of the Maya sitatungas (Sinclair 1977; Mloszewski 1983; OwenSmith 1990). A question arises as to what extent the increase in the size of the Maya sitatunga group, especially the greater number of females, has repercussions for the reproductive success of both sexes. First, it could increase the cost of the monopolization of females by the adult male. In this context, females could mate with a subordinate male or with a stranger, especially at night in the forest. Second, adult females might not be able to control the access of young adult females, either resident or immigrant, to the reproductive male and could suffer from a reduction of this access (e.g., Dunbar 1984; Whitten 1984; Cheney et al. 1988). Although this hypothesis is more likely to be supported when mating is synchronized, the fact that some females born at the clearing did not emigrate despite the aggressiveness of the adult females could indicate that the latter cannot control the whole female population. Female reproductive success could also decline with the increase in group size if feeding resources became a limiting factor (Clutton-Brock 1988). In all cases, an increase in female aggressiveness can be expected. In fact, the number of chases by adult females per day varied from 0.4 in 1996-1997 to 0.9 in 1998 when immigrant females were included in the calculation, and from 0.3 to 0.4 when only philopatric young females were taken into account. Although these tendencies tend to support our hypothesis, they are not completely convincing. Finally, the tenure of the adult male, which exceeds one generation, could also favour incestuous mating and cause a decline in genetic diversity. In the long term, avoidance of inbreeding could be the ultimate factor that would induce young females to emigrate (e.g., Harcourt 1978; Rutberg and Keiper 1993; Monard and Duncan 1996).

A long-term study of the Maya sitatungas, as well as comparative studies at other clearings and in surrounding forests, are needed to answer remaining questions. Presently, in addition to providing an argument in favour of a relationship between food availability and grouping patterns, our results underline the plasticity of inter-individual relationships and mating strategies of male and female sitatungas. Indeed, the few data available on other populations describe unstable groupings and suggest the occurrence of polygamous mating.

\section{Acknowledgements}

The authors thank AGRECO - Groupement Européen d'Intérêt économique and the European Ecologie et Conservation des forêts d'Afrique Centrale (ECOFAC) program for technical and financial support. We are grateful to J.M. Froment, ECOFAC-Congo project leader, who did everything possible to ensure the success of this study. Special thanks are extended to the field research assistants, H. Bongo-Passi,
R. Kibiele, J.B. Nganongo, S. Oyandzi, and S. Yaba Ngouma, and to B. Davidson, M.C. Fleury, J.B. Nganongo, and H. Vanleeuwe, who communicated their group counts for Maya sitatungas. Thanks are extended to A. Cloarec for English revision and to Dr. N. Owen-Smith for helpful comments.

\section{References}

Cheney, D.L., Seyfarth, M.R., Andelman, S.J., and Lee, P.C. 1988. Reproductive success in vervet monkeys. In Reproductive success. Edited by T.H. Clutton-Brock. University of Chicago Press, Chicago. pp. 384-402.

Clutton-Brock, T.H. 1988. Reproductive success. In Reproductive success. Edited by T.H. Clutton-Brock. University of Chicago Press, Chicago. pp. 472-485.

Crook, J.H. 1970. Social behavior in birds and mammals. Academic Press Inc., London.

Dunbar, R.I.M. 1984. Reproductive decisions: an economic analysis of Gelada baboon social strategies. Princeton University Press, Princeton, N.J.

Emlen, T., and Oring, T.W. 1977. Ecology, sexual selection, and evolution of mating systems. Science (Washington, D.C.), 197: 215-223.

Estes, R.D. 1971. Social organization of the African Bovidae. In The behavior of ungulates. Vol. 1. New Series No. 24. Edited by V. Geist and F. Walther. International Union for the Conservation of Nature and Natural Resources, Morges, Switzerland. pp. 166-205.

Gautier-Hion, A., Emmons, L.H., and Dubost, G. 1980. A comparison of the diets of three major groups of primary consumers of Gabon (primates, squirrels and ruminants). Oecologia, 45: 182189.

Gosling, L.M. 1986. The evolution of the mating strategies in male antelopes. In Ecological aspects of social evolution. Edited by D.I. Rubenstein and R.W. Wrangham. Princeton University Press, Princeton, N.J. pp. 244-281.

Harcourt, A.H. 1978. Strategies of emigration and transfer by primates, with particular reference to gorillas. Z. Tierpsychol. 48: 401-420.

Hecketsweiler, P., Doumenge, C., and Mokoko Iconga, J. 1991. Le Parc National d'Odzala (Congo). International Union for the Conservation of Nature and Natural Resources, Gland, Switzerland.

Jarman, P.J. 1974. The social organization of antelope in relation to their ecology. Behaviour, 48: 215-268.

Kingdon, J. 1982. Tragelaphines. In East African mammals. Vol. IIIC. Academic Press, London. pp. 72-105.

Klaus-Hügi, C. 1998. Home range, feeding behaviour and social organization of the bongo (Tragelaphus euryceros) in the rain forest of the Central African Republic. Ph.D. thesis, University of Zürich, Zürich, Switzerland.

Magliocca, F. 2000. Etude d'un peuplement de grands mammifères forestiers tropicaux fréquentant une clairière au Congo : structure des populations; utilisation des ressources; coexistence intra- et inter-populationnelle. Ph.D. thesis, University of Rennes 1, Rennes, France.

Magliocca, F., and Gautier-Hion, A. 2002. Mineral contents as a basis for food selection by western lowland gorillas in a forest clearing. Am. J. Primatol. In press.

Malbrant, R., and MacLatchy, A. 1949. Faune de l'équateur africain français. Tome II : Mammifères. P. Lechevalier, Paris. 
Manning, I. 1983. Ecology of the sitatunga Tragelaphus spekei selousi in the Bangweulu swamps, Zambia. M.Sc. thesis, Acadia University, Wolfville, N.S.

Mloszewski, M.J. 1983. The behavior and ecology of the African buffalo. Cambridge University Press, Cambridge.

Monard, A.M., and Duncan, P. 1996. Consequences of natal dispersal in female horses. Anim. Behav. 52: 565-579.

Owen, R.E.A. 1970. Some observation on the sitatunga in Kenya. East Afr. Wildl. J. 8: 181-195.

Owen-Smith, N. 1990. Demography of a large herbivore, the greater kudu Tragelaphus strepsiceros, in relation to rainfall. J. Anim. Ecol. 59: 893-913.

Rubenstein, D.I. 1986. Ecology and sociality in horses and zebras. In Ecological aspects of social evolution. Edited by D.I. Rubenstein and R.W. Wrangham. Princeton University Press, Princeton, N.J. pp. 282-302.

Rutberg, A.T., and Keiper, R.R. 1993. Proximate causes of natal dispersal in feral ponies: some sex differences. Anim. Behav. 46: 969-975.

Sinclair, A.R.E. 1977. The African buffalo. Wildlife Behavior and Ecology Series, Chicago University Press, Chicago.

Starin, E.D. 2000. Notes on sitatunga in the Gambia. Afr. J. Ecol. 38: 339-342.

Sterck, E.H.M., Watts, D.P., and van Schaik, C.P. 1997. The evolution of female social relationship in nonhuman primates. Behav. Ecol. Sociobiol. 41: 291-309.

Vanleeuwe, H., Cajani, S., and Gautier-Hion, A. 1998. Large mammals at forest clearings in the Odzala National Park, Congo. Rev. Ecol. Terre Vie, 53: 171-180.

Verhrencamp, S.L. 1983. A model for the evolution of despotic versus egalitarian societies. Anim. Behav. 31: 667-682.

Whitten, P.L. 1984. Competition among female vervet monkeys. In Female primates: studies by women primatologists. Edited by M.F. Small. Alan R. Liss, New York. pp. 127-140. 